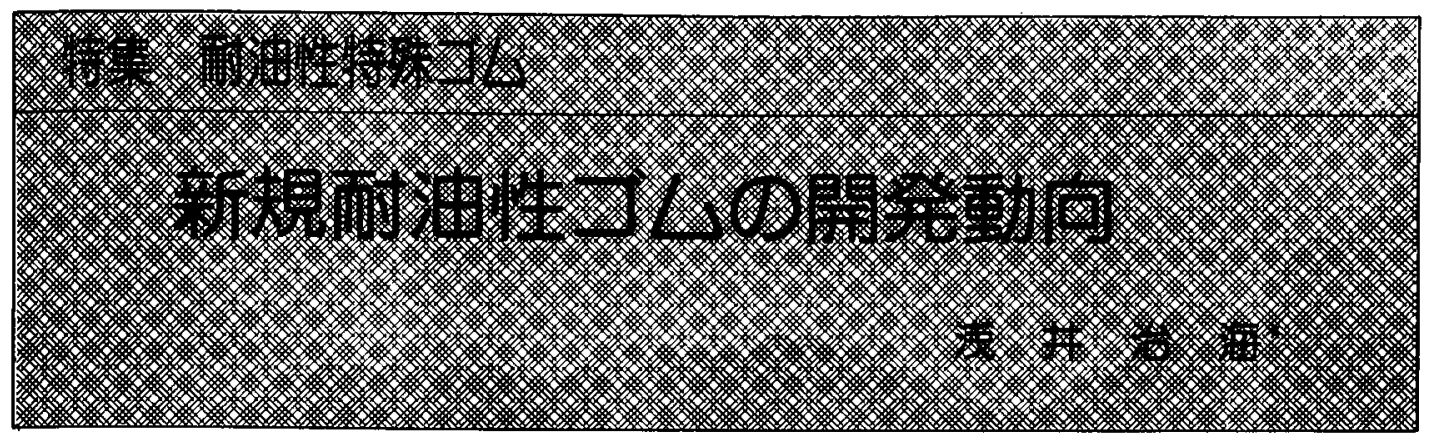

1.はじめに

ゴム製品に関する性能上の要求は，ますます高機能化 する方向にある. ゴム製品を利用する自動車産業，エネ ルギー産業などからの要求は，多様化し，極限化してき ている. その要求の一つに耐油性の向上がある.

耐油性の向上には，耐油性の極限を求めるものと，現 在の耐油性のレベルではあるが耐油性以外の特性の向上 を期待してバランスのとれた耐油性ゴムを目ざすものと がある. そのために，新しい耐油性のポリマーの開発が 行われたり, 新しいポリマーの組合せが检討されたり， また，新しい配合による性能向上が試みられている。

ここでは，耐油性，耐溶剂性ゴム開発の最近の二，三 の動きについて簡単に述べることにしよう.

\section{2. 耐油性ゴムをとりまく動き}

耐油性ゴムの加硫物の耐油性及ひ耐溶剤性をまとめて 示したのが表 1 である。この表から理解されるように， なかなか万能の耐油性ゴムを見出すことはむずかしく， 耐油性以外の性能とのバランスもあって, 種々のポリ マーの組合せに関する検討が最も多い，この耐油性を求 める市場動向について考えてみよう。

\section{1 自動車と耐油性ゴム}

自動車をとりまく動きとゴム材料倸対する耐油性など の要求という面からながめてみると，大きく分けて環境 問題と燃料問題がある.

環境の污染を防止するために，自動車の排気ガス規制 が行われ，炭化水素排出量規制がなされた. 排気ガス対 策としてガソリンの無鉛化を行うためにガソリンの組成 を変更して芳香族成分を増加させるには，耐芳香族含有 ガソリン性の向上したゴムが必要となる. 炭化水素排出 規制に伴なってゴムのガソリンの透過性を考虑する必要 がありゴムの耐油性，耐ガンリン透過性などが問題2と なる.
然料問題からは燃費の節約のためにエンジンの改良が 加えられて耐油性, 耐熱性の優れたゴムが必要となり， 石油の節約のためにアルコール混合ガンリンが利用され るようになると耐アルコール含有ガソリン性の優れたゴ ムが求められ27)，然料を有効利用するために燃焼の最適 化がはかられて然料噴射装置が利用されるようになると ガソリンが変質してサワー化しゴムの劣化を促進するの で耐サワーガソリン性の高いゴムが要求される2).

また，自動車にもメインテナンスフリーが求められ て，使用するゴム材料にますます高い信頼性と耐久性が 求められ，耐熱性などへの要求がより強くなってきてい る.

アルコール含有ガソリンの実用化はすでに米国やブラ ジルで進んでいる. アルコールとしてはエチルアルコー ルが用いられ，米国では現在 1 年間に 200 万 $\mathrm{k} l$ のル コールが利用されているが，2000年には400万 $\mathrm{k} l$ に達す ると予想される ${ }^{3)}$. ブラジルでは現在760万 $\mathrm{k} l$ の消費で あるが，1987年には1,430万 $\mathrm{k} l$ に達し，すでにエチルア ルコールだけで動く自動車は100万台(累計)に達してい るといわれる3). しかし，日本や西ドイッではバイオマ スの生産力に限度があることから，メチルアルコールの 利用が検討されている. 多くのゴム材料はガソリンのみ よりもメチルアルコールーガソリン混合物によってその 物性が大きく低下する.このとき，架橋した膨閵ゴムの 引張強さと伸びは体積膨润度と簡単な直線関係で定量的

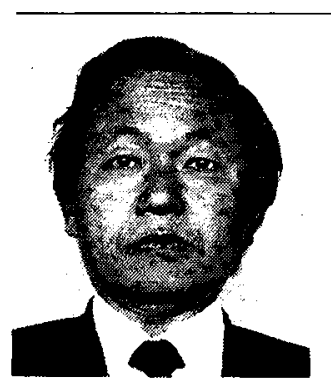

*日本ゼオン继(テ153 東京都 目黑区東山1-1-2)昭和29年京 都大学理学部化学科卒業. 工 博. 36年日本ゼオン侏)入社. 現在に至る。 〈趣味〉石仏観賞. 
表 1 预油性ゴムの性能

\begin{tabular}{|c|c|c|c|c|c|c|c|c|c|c|}
\hline \multirow[b]{2}{*}{ 原料ゴム } & \multicolumn{5}{|c|}{ 加硫ゴム耐油性 } & \multicolumn{5}{|c|}{ 加硫ゴム耐溶剂性 } \\
\hline & $\begin{array}{l}\text { ガソリ } \\
\text { 油・軽 } \\
\text { 滛 }\end{array}$ & $\begin{array}{l}\text { ベンゼ } \\
\text { ン・ト } \\
\text { ルエン }\end{array}$ & $\begin{array}{l}\text { 動植物 } \\
\text { 油 }\end{array}$ & $\begin{array}{l}\text { ジェス } \\
\text { テル系 } \\
\text { 潤滑油 }\end{array}$ & $\begin{array}{l}\text { リン酸 } \\
\text { 委压方 } \\
\text { 作陲油 }\end{array}$ & $\begin{array}{l}\text { トリク } \\
\text { レン }\end{array}$ & $\begin{array}{l}x チ ル \\
ア ル コ \\
-ル\end{array}$ & $\begin{array}{l}\text { メチル } \\
\text { エチル } \\
\text { ケトン }\end{array}$ & $\begin{array}{l}\text { 酰酸エ } \\
\text { チル }\end{array}$ & $\begin{array}{l}\text { エーテ } \\
\text { ル }\end{array}$ \\
\hline ニトリルゴム & (2) & $\triangle$ & (a) & $x$ & $x$ & $\Delta$ & $\square$ & $x$ & $x$ & $\square$ \\
\hline クロロプレンゴム & 0 & $\times$ & 0 & $x$ & $\triangle$ & $x$ & $\overline{0}$ & $\triangle$ & $\triangle$ & $x$ \\
\hline ウレタンゴム & (a) & $\triangle$ & (a) & $\square$ & $\triangle$ & $x$ & $x$ & $x$ & $x$ & 0 \\
\hline エピクロルヒドリンゴム & (a) & $\triangle$ & (a) & $\square$ & $x$ & $x$ & $\square$ & $x$ & $x$ & 0 \\
\hline フッ素含有エラストマー & (a) & (a) & (a) & 0 & $\triangle$ & (Q) & $\triangle$ & $x$ & $x$ & $x$ \\
\hline アクリルゴム & 0 & $x$ & (a) & $x$ & $x$ & $x$ & $x$ & $x$ & $x$ & $x$ \\
\hline シリコーンゴム & $\triangle$ & $\triangle$ & (O) & $\square$ & $\triangle$ & $\mathrm{O}$ & 0 & 0 & 0 & $x$ \\
\hline $\begin{array}{l}\text { クロロスルホン化ポリエ } \\
\text { チレン }\end{array}$ & $\square \sim 0$ & $\triangle$ & $\mathrm{O}$ & $x$ & $\triangle$ & $x$ & (O) & $\triangle$ & $\triangle$ & $x$ \\
\hline 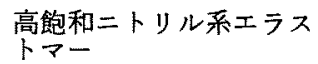 & (a) & $\triangle$ & (C) & $\Delta \sim 0$ & $\triangle$ & $\triangle$ & $\square$ & $x$ & $x$ & $\square$ \\
\hline
\end{tabular}

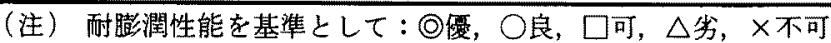

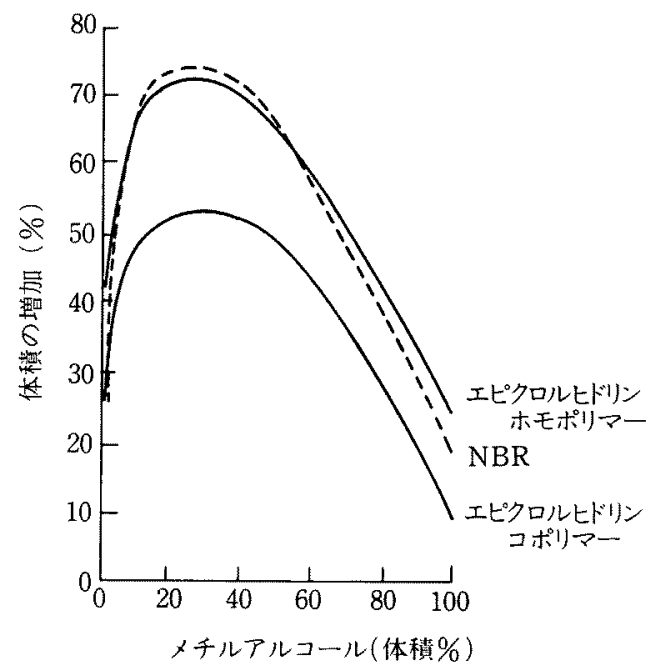

図 1 メチルアルコール含有ガソリンによる膨潤4) ガソリン：全芳香族含有率 $42 \mathrm{vol} . \%$

夹験条件：21 ${ }^{\circ} \mathrm{C} 20$ 日間

に示される4!．図1にメチルアルコール含有ガソリンに よる膨潤の一例を示した。メチルアルコールのみを利用 する自動車の開発も進められており，1985年度には宅配 便トラックや都バスを対象に走行テストが行われる予定 である。

ガソリンが高温下に酸素にさらされるとペルオキシド が生成する．これを多量に含有するガソリンをサワーガ ソリンという。耐サワーガンリン性のゴムとしてはフッ 素含有エラストマーに加えて，エピクロルヒドリンゴ $\Delta^{6}$ ，酸化防止剂を分子内に結合させた $\mathrm{NBR}^{7 / 8)}$ や高飽
和型ニトリル系エラストマー9)10）登場している。

\section{2 エネルギー関係}

石油の井戸は石油価格の高騰に伴ってより潹くまで掘 り進むようになった、深井が多くなると, 高温, 二酸化 炭素, 硫化水素の影響も大となり，より優れた酎油性に 加えてこのような深井の条件に耐えられるゴム材料が求 められる。

新しいエネルギー源として，地熱の利用が火山国で積 極的にすすめられているが，この場合には高熱の地下の 塩分を多量に含んだ水, 熱交換に用いられる媒体などに 耐える材料が要求される.

原子力発電でも，六フッ化ウランやフッ素系潤滑剤に 耐える信頼性の高いゴム材料が必要である。

\section{3 宇宙産業関係ほか}

ジェットエンジン，ミサイル，スペース・シャトルな どにも高温や低温に耐える特種な耐油性ゴムのニーズが ある。

船舶の場合，海水污濁防止やシールの寿命長期化のた めに耐油性に優れたフッ素含有エラストマーへの切替え が進んでおり，食品機械でも安全性，涌油性の雨面から ゴム材料の選択が進められている.

\section{4 耐油性ゴム材料の動问}

NBR は耐油性の特殊ゴムとして，自動車部品を中心 に高機能化，高珄能化が積極的に進められており，単に 耐油性だけでなく耐サワーガソリン性，耐熱性などの特 性が求められており，高度の高機能性特殊ゴムに近い性 質のものもできている。

CR はある程度の耐油性を持ち, 耐候性とのバランス がとれたゴム材料として伸びており，耐熱性の向上によ 
ってより需要が㹡大しよう.

自動車業界が成長期から成熟期に入ったことによっ て，量から質への転换が進められつつあり，これに伴っ て自動車用ゴム部品に対する要求性能はより高度化し， これに対応してアクリルゴム, エピクロルヒドリンゴ ム，フッ素含有エラストマーなどの利用が進んでいる。 また，種々の耐油性合成ゴムの品質向上がますます進め られ，多品種化の㑯向は強まるであるう。

\section{3. ニトリル系エラストマー}

NBR は優れた耐油性ゴムであり，更にその耐油性を 向上させるために他の材料を併用する方法やポリマー自 体を改質する万法がとられる。

\section{1 他のポリマーとの組合せ}

ガソリン中の芳香族成分が增加すると，NBR 配合物 でも溶阂き裂現象がおきて実用上問題になることがある と考えられる、しかし，ブタジェン又はイソプレンとア クリロニトリル，2-ビニルピリジン又はメタクリ酸の数 平均分子量が約500〜1,000である液状三元コポリマーを 添加すると，大幅に溶剂き裂現象が改善された耐油性組 成物が得られる(表 2 の No.11及びNo. 12)，ここで, ビニルピリジンのコポリマー中の含有量は $0.1 \%$ 以下で
は耐溶郕き裂性が改善されず，40\%以上ではゴム弾性， 耐寒性が低下し，分子量が上記の範囲以下では抽出され やすくて圧縮永久ひずみが少り，以上では耐溶郕き裂性 が向上しない．また，メタクリル酸の量が0.1\%以下で は耐溶剤き裂性が改善されす，10\%を超えると耐溶剂き 裂性及び他の物性が低下寸るので好ましくない，

そのほか, 特定構造のポリブタジエン，塩化ビニリデ ン樹脂，フッ素含有エラストマーなどの利用が検討され ている(表 2 参照).

\section{2 新しい耐油性ニトリル系エラストマー}

\subsection{1 新しいニトリル系エラストマー}

ニトリル基を持ち，NBRの耐油性と耐寒性を保ちな がら耐薬品性や耐熱性を大幅に改良された新しいエラス トマーが開発された。 このエラストマーは側鎖のニトリ ル基で耐油性を持たせ，主鎖のメチレン鎖で耐熱性，化 学的安定性, ゴム弾性を与え, 少量の炭素一炭素二重結 合によって架橋することができる高飽和型ニトリル系エ ラストマーであり ${ }^{9)}$ ，耐熱性に優れ，酎寒性，耐油性の バランスがよく，耐オゾン性，耐スチーム性，耐薬品 性，強度的性質に優れ，PVCと上く相溶する9)。 耐熱油性，耐サワーガソリン性がよく，種々の潤滑油添 加剤に対して安定であって，引張強さは低下しない9．

表 2 ポリマーを利用してNBKの酎油性を保ちながらその他の特性を改善した最近の例

\begin{tabular}{|c|c|c|c|}
\hline No. & ポリマー & 果 & 文 \\
\hline 1 & 特定構造の BR & $\begin{array}{l}\text { 耐油膨潤性をプラスに維持し，収樎割れの発生を } \\
\text { 防ぎ，疲労寿命の改善 }\end{array}$ & 特開昭58一-78754 \\
\hline 2 & $\begin{array}{l}\text { 塩化ビニリデン樹脂 (ビニリデン } \\
\text { 含有量75\%以上) }\end{array}$ & 耐油性と耐寒性のバランスに優れている & 特開昭57-177034 \\
\hline 3 & $\begin{array}{l}\text { ポリ塩化ビニル(特定粒子经を保 } \\
\text { 持したまま均一分散させる) }\end{array}$ & $\begin{array}{l}\text { 高充てん時の加工が容易で耐油性・耐オゾン性を } \\
\text { もつ }\end{array}$ & 特開昭59-45339 \\
\hline 4 & ハログン化ブチルゴム & 溶出物が少なく耐油性に優れる & 特開昭58一-39436 \\
\hline 5 & EPDM & $\begin{array}{l}\text { 加硫物の強度, 伸びなどが著しく改善され，耐油 } \\
\text { 性，耐候性，耐オジン性に優れる }\end{array}$ & 特開昭59-27931 \\
\hline 6 & $\mathrm{EPDM}+$ ポリオレフィン & CR以上の䙳油性と酎オン゙ン性を持っ & 特開昭57-96032 \\
\hline 7 & 塩素化ポリエチレン & 加工珄の改善 & 特開昭57-119943 \\
\hline 8 & 塩素化 EPDM & $\begin{array}{l}\text { 両ゴムの耐油性, 耐候性を持ち, 機械的性質に優 } \\
\text { れる }\end{array}$ & 特開昭59-71345 \\
\hline 9 & 変性 EPDM & $\begin{array}{l}\text { 耐オゾン性，耐熱老化性，耐溶绪性を兼ね備え, } \\
\text { 的性賣に優れる }\end{array}$ & $\begin{array}{l}\text { 特開昭57-40544 } \\
\text { 及び } 44647\end{array}$ \\
\hline 10 & $\begin{array}{l}\text { フッ素含有エラストマー（フッ化 } \\
\text { ビニリデンーヘサフルオロプロ } \\
\text { ピレン-テトラフルオロエチレン } \\
\text { 光共重合体) }\end{array}$ & $\begin{array}{l}\text { 常態物性, 耐熱性, 耐サワーガソリン性, 耐アル } \\
\text { コール含有ガソリン性, 加工性に優れる }\end{array}$ & $\begin{array}{l}\text { 特開昭 } 57-135843 \text { ， } \\
135844\end{array}$ \\
\hline 11 & $\begin{array}{l}\text { ブタジェンービニルピリジンーアク } \\
\text { リロシトリル共重合体 }\end{array}$ & 高芳香族系溶剤中でのき裂成長が小さい & 特公昭56-49942 \\
\hline 12 & $\begin{array}{l}\text { ブタジェンーメタクリル酸ーアクリ } \\
\text { ロニトリル共重合体 }\end{array}$ & 同上 & 特公昭50-27486 \\
\hline
\end{tabular}




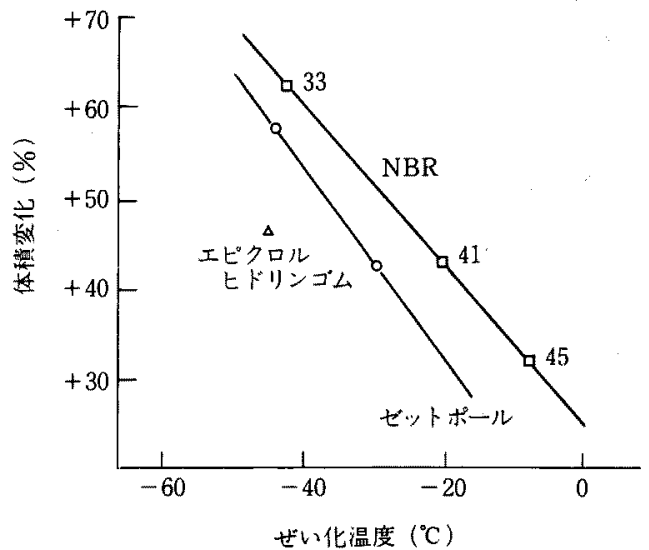

図 2 高飽和ニトリル系エラストマー(ゼットポール)の 耐油性と耐寒性 ${ }^{5}$ )

件：燃料油 C $40^{\circ} \mathrm{C} \times 48 \mathrm{hrs}$

このエラストマーはその特性を生かして，然料系ゴム部 品, 潤滑油系ゴム部品, 油圧機器系ゴム部品, その他の 工業用品に利用される99.

これらの特性を有する日本ゼオンが開発したエラスト マー(ゼットポール)の耐寒性を図 2 に，耐ガソリン性を 図 3 に示した。また，Bayer 社の開発したTherban は34 \%のアクリロニトリルを含む新しい嘼熱性, 耐油性のエ ラストマーで, 密度が $0.945 \mathrm{~g} / \mathrm{cm}^{3}$ で, メチルエチレン ケトンや塩素化炭化水素に溶解するとき不溶部分が残ら ず，耐寒性に優れている10)，また，このエラストマーは 優れた耐然料油性を示し，例えば標準原油中 $150^{\circ} \mathrm{C}$ で長 期にわたり引張強さはほとんど变化せず, サワーガンリ

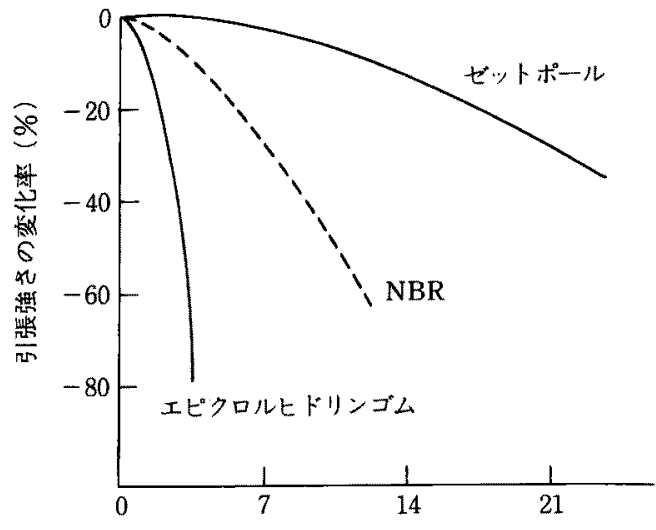

浸せき日数(日)

図 3 高飽和ニトリル采エラストマー(ゼットポール)の 耐ガソリン性

条件：燃料油 B(ラウリルペルキオキシド $1 \%$ 含 有) $60^{\circ} \mathrm{C}$

ンによる $60^{\circ} \mathrm{C} ， 7$ 日間の浸せきテストによる膨潤は+62 \%である(0). 油井関連分野で要求されるエラストマーで は，耐油性や耐熱性に加えて硫化水素やアミンの働きに も耐えることが必要であるが，アミン類を含有する ASTM \# 3 油によるテストでは, Therbanはフッ素含 有エラストマーやNBR と比較して満足すべき結果を与 える10!

\section{2 .2 メチエチレンケトン不溶分を含む NBR ${ }^{11)}$}

限定された範囲内でメチルエチレンケトン不溶分を含 み，メチルエチレンケトン可溶分が低分子量成分と高分

表 3 Therban の膨潤性 ${ }^{9)}$

\begin{tabular}{|c|c|c|c|c|c|c|c|c|c|c|c|c|c|c|}
\hline \multirow{2}{*}{\multicolumn{2}{|c|}{$\frac{\text { 膨 潤 }}{\text { ASTM\# } 2 \text { 油 }}$}} & 剂 & \multicolumn{2}{|c|}{ 実験条件 } & & \multirow{2}{*}{$\begin{array}{r}\% \\
+11\end{array}$} & & \multirow{2}{*}{$\begin{array}{r}\% \\
+12\end{array}$} & \multirow{2}{*}{$\triangle F$} & \multirow{2}{*}{$\begin{array}{r}\% \\
+11\end{array}$} & \multirow{2}{*}{\multicolumn{2}{|c|}{$\begin{array}{r}\triangle \mathrm{D} \% \\
+16\end{array}$}} & \multirow{2}{*}{\multicolumn{2}{|c|}{$\begin{array}{r}\Delta \mathrm{H} \quad \% \\
-9\end{array}$}} \\
\hline & & & $150^{\circ} \mathrm{C}$ & 7 日 & & & & & & & & & & \\
\hline & & & & 14 日 & & +11 & & +12 & & +10 & & +16 & & -9 \\
\hline \multirow{2}{*}{\multicolumn{3}{|c|}{ ASTM\# 3 油 }} & $150^{\circ} \mathrm{C}$ & 3 日 & & +17 & & +20 & & \pm 0 & & +12 & & -13 \\
\hline & & & & 7 日 & & +20 & & +25 & & -20 & & -18 & & -13 \\
\hline \multirow{2}{*}{\multicolumn{3}{|c|}{$\begin{array}{l}20 \% \mathrm{H}_{2} \mathrm{~S} \text { 含有 ASTM \# } 3 \text { 油 } \\
\text { モーター油 SAE } 20 W 20\end{array}$}} & $150^{\circ} \mathrm{C}$ & 1 日 & & 一 & & - & & +7 & & -24 & & +4 \\
\hline & & & $150^{\circ} \mathrm{C}$ & 14 日 & & +4 & & +4 & & +13 & & -39 & & -5 \\
\hline \multicolumn{3}{|l|}{ 制動油 } & $50^{\circ} \mathrm{C}$ & 28 日 & & +13 & & +14 & & -2 & & -4 & & -11 \\
\hline \multicolumn{3}{|c|}{ グリコール/水/防蝕油 } & $140^{\circ} \mathrm{C}$ & 14 日 & & +32 & & +35 & & -26 & & -5 & & -12 \\
\hline \multicolumn{3}{|c|}{ サワーガソリン } & $60^{\circ} \mathrm{C}$ & 7 日 & & +45 & & +62 & & -61 & & -50 & & -21 \\
\hline \multicolumn{3}{|c|}{ ジーゼル油 } & $70^{\circ} \mathrm{C}$ & 70時間 & & +16 & & +22 & & -8 & & -11 & & -17 \\
\hline
\end{tabular}

（注） $\triangle G:$ 重量変化

$\triangle \mathrm{V}:$ 体積変化

$\triangle F:$ 引張強さの変化

$\triangle \mathrm{D}:$ 引張り切断時の伸びの変化

$\triangle \mathrm{H}$ : Shore A 硬さの変化 
子量成分を持っNBRは，低硬度で加工性に優九耐溶剤 抽出性，酎熱性に優れる，メチルエチレンケトン不溶分 はジビニルベンゼンのような多官能モノマーを共重合す ることによって得られ，目的とする特定構造の NBR を 得るには混合などの工夫が必要である.

\subsection{3 老防共重合 NBR}

老化防止剂を共重合させることによって，NBRの高 温時における老化防止剂の揮散やガンリン・潤滑油など による抽出が防止できるので耐久性が向上する。アル コールやサワーガソリンにも優れた性能を示す，共重合 性の老化防止剤としては，N-(アミノフェニル)メタク リアミドリ，ジフェニルアミド誘導(体帛などが用いられ， このゴム材料は自動車部品, 工業用品に利用される.

\subsection{4 $\alpha ， \beta$-不能和ニトリル-共役ジエンー(メタ)ア クリル酸フルオロアルキル三元共重合エラスト จ-}

アクリロニトリル，ブタジェン，1,1-ジヒドロペルフ ルオロエチルアクリレートよりなる三元共重合エラスト マーは, 耐サワーガソリン性, 耐アルコール含有ガソリ ン性に優九，硫黄架橋が可能で常態物性のバランスのと れたエラストマーである12).ここで,このエラストマー の特性のバランスを保つために，各成分は商当な含有モ ル比を保つことが必要である. 例えば，(メタ)アクリル 酸フルオロアルキルの含有量が 2 モル\%未泗では, 耐サ ワーガソリン性などの向上は期待されず，55モル\%以上 では耐寒性に少る12).

NBR と塩化ビニル樹脂のブレンドによって耐サワー ガソリン性の改良が行われることが知られている ${ }^{13}$ が, 常態物性, 耐寒性, 压縮永久ひずみなどが檥牲とな $3^{12)}$. 上述のアクリロニトリルーブタジェンー1,1-ジヒド ロペルフルオロエチルアクリレート三元共重合エラスト マーをNBRの代りに用いると，然料用ゴム材料として 優れた耐サワーガソリン性，耐アルコール含有ガソリン 性を持つとともに，常態物性，耐寒性，压縮永久ひずみ のバランスのとれたゴム組成物が得られる12).

\section{$3.2 .5 \alpha, \beta$-不勘和ニトリル-共役ジエンーフッ素化 $\alpha$} ーオレフィン三元共重合エラストマー

耐サワーガソリン性，耐アルコール含有ガソリン性に 優れ，硫黄架橋が可能で優れた物性バランスをもつゴム 素材として，アクリロニトリル，ブタジンンククロト リフルオロチレン，又はジクロロジフルオロエチレンの 三元重合エラストマーが開発された ${ }^{14)}$.

このコポリマーも塩化ビニル樹脂と併用すると， NBR を用いることによって改良される場合と此較して，
圧縮永久ひずみなどがよりょくなることに加えて引張强 さや，耐寒性が向上する ${ }^{(4)}$.

\section{2 .6 その他}

NBR の耐サワーガソリン性を改善するために，ウレ タンーイオウ $(80$ 部 $/ 20$ 部)混合架橋㓮を用いると 6 時間の 老化テスト後の架橋物の物性は, 硫黄架橋した NBR 配 合物や 3 週間テストした後のエピクロルヒドリンゴム配 合物の物性よりも優れている ${ }^{15}$.

液体 NBR は難抽出性, 非揮発性の可塑㓮として利用 される。これをNBR を成分とするゴム製品に配合する と耐ガソリン性, 耐動的疲労性が改善されたものが得ら れる.

\section{4. フッ索含有エラストマー}

フッ素含有エラストマーは種々のフッ素化炭化水素モ ノマーを共重合させたポリマーである.モノマーとして は, フッ化ビニリデン, テトラフルオロエチレン, へキ サフルオロプロピレン, 1-ヒドロペンタフルオロプロピ レン, ペルフルオロ(メチルビニルエーテル)，及び架橋 のためのモノマーが組合せて用いられる，通常フッ素含 有エラストマーのフッ素の含有量は65～69\%である.

このエラストマーは耐熱性, 耐油性に優れており, 化 学用プラントのパッキング材, シール材などに用いられ てきた，近年，自動車の排気ガス規制が害施されてから エンジンルーム内の高温に耐えることのできるエラスト マーとして脚光を浴び，乗用車の FF 化やターボ化に伴 って需要が伸びてきた。 また，このエラストマーはフッ 秦の含有量によって低温での可撓性, 耐化学薬品性が急 激に変化する。例えば，フッ素含有量が $65 \% ， 67 \% ， 69$ \%と変化すると，エラストマーのガラス転移温度は一 22 ${ }^{\circ} \mathrm{C},-19^{\circ} \mathrm{C},-9{ }^{\circ} \mathrm{C}$ 上昇し, 室温で7日間のメタノー ルによる䁶潤度は $120 \% ， 25 \% ， 2 \%$ と低下する ${ }^{16)}$.

フッ素含有エラストマーのASTM 標準試料 C の平衡 透過速度は NBR(28\%アクリロニトリル含有)に比べて その $1 \%$ 以下に拉さえることができ，ホース用の耐油性 エラストマーとして優れた特性を有する.

油井の環境では, 高温に耐え, 広範囲の炭化水素, 硫 化水素, 水, 二酸化炭素, ブラインに耐えるエラスト マーが要求される，100 150 $0^{\circ} \mathrm{C}$ で硫化水素や酸性液体の

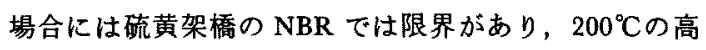
温でもフッ素含有エラストマーであればこの環境に充分 使用できる17).

地熱エネルギーを取出すのにも，耐ブライン性，耐熱 性からみてフッ素含有エラストマーが適している18). 


\section{1 新しいフッ素含有エラストマー}

Kalrez(du Pont) (テトラフルオロエチレン, ペルフ ルオロ(メチルビニルエーテル)，架橋用モノマーよりな る)の最大の特徴は罘熱性で，連続使用では $288^{\circ} \mathrm{C}$, 一時 的には $315^{\circ} \mathrm{C}$ 高温に耐え，耐溶郕性は他のフッ素含有 エラストマーよりも優れている19). その特性から, 石油 や天然ガスの採掘，スペースシャトルなどの航空機産 業, 半導体製造機器への利用が期待され，近年石油掘削 深度がより㳭くなりつつあり，これに使える有望なゴム 材料となろう。

エラストマー鎖と非エラストマー鎖からなるフッ素含 有熱可塑性エラストマーが開発された。この熱可塑性エ ラストマーは添加剤や架橋工程を必要としない，故に純 粋の素材で高信頼性の要求される医薬, 食品, 半導体の 分野に適している ${ }^{20)}$ ：透明性が高く，純粋な成形品が簡 単に安い加工費で得られ, 成形品の再使用が可能であ る21．このエラストマーを素材として半導体製造分野に まとを絞ったシール材も上市されたが，このシール材の 強度等を向上させるために放射楾による架橋が行われて (る ${ }^{22)}$.

この熱可塑性のフッ素含有エラストマーの溶液又は分 散体は, 耐熱性, 酎油性, 酎溶剂性, 耐スチーム性, 耐 酸化性などに優れた塗料組成物を与える23). フッ素含有 エラストマー,フッ素樹脂，アミノシラン及び液状担体 よりなる塗料の塗膜をつくらせることにより，潤滑油で 贫化せす弾性，シール性を保つ耐潤滑油性シール材が得 られる24).フッ菜含有エラストマーのカプセルを利用す ると，熱や腐蝕に强い塗料が得られる、フッ素含有エラ ストマーの特性を生かした非粘着性, 潤滑性が加わった 水性塗料も開発された.

そのほ加，食品衛生法に適合し，熱水や水蒸気，無機 酸に優れた耐性を持つタイプ，可塑剤の添加が必要でな い低硬度のもの，低压縮永久ひずみタイプのものなどが 開発されている。

\section{2 フッ奉含有エラストマーのブレンドと接著}

NBR とフッ素含有エラストマーをブレンドする場合， 後者を連続相にすることによって耐劣化ガソリン性を向 上させることが可能である ${ }^{25)}$. 分散剂としてエチレンア クリレートエラストマーを添加するとフッ素含有エラス トマーの量を少なくしても連続相となるので耐熱性と耐 㸓化ガソリン性が向上するが，耐アルコール含有ガソリ ン性は低下する25).

NBR 層とフッ素含有エラストマー層からなるゴム製 品を製造する場合に，雨層に1,8-ジアザビシクロ
[5.4.0]ウンデセン-7塩 ${ }^{26}$ や特定量( $3 \sim 20$ 部)の酸化再 鉊 ${ }^{27)}$ を配合することにより強固な接着強度の層状檴造物 が得られる.

\section{5. エピクロルヒドリンゴム}

エピクロルヒドリンゴムは耐油性，耐熱性，耐候性に 優れた合成ゴムである。

自動車の排気ガス対策のために多種の特性をバランス よく備えたゴム組成物が要求されている，これにこたえ るために，耐熱性，耐油性，耐候性などの面からクロロ プレンゴムとエピクロルヒドリンゴムのブレンド系が檢 討されてきたが，層状はく離強度が低いのが問題であ る.ここて，第三成分として NBR を用いたブレンド系 では，優れた層状はく離強度，耐屈曲性，耐熱性，耐才 ゾン性をもった耐油性ゴム組成物が得られる

エピクロルヒドリンーエチレンオキシド共重合ゴムは 䩂油性，耐熱性，耐寒性に優れているが，サワーガソリ ンによって軟化出化するという久点がある。この欠点は アリルグリシジルエーテルのような不飽和エポキシドを 第三成分とする三元共重合ゴムとすることにより解決さ れた6)。この場合，架橋反応には不飽和エポキシドの不 飽和結合注利用せず，サワーガソリン中の過酸化物がゴ ムの主鎖を切断しても同時にこの飽和結合と反心して架 橋物の軟化を防止するのに利用される6).この三元共重 合ゴムの耐複合体オゾンき裂性はクロルスルホン化ポり エチレンよりも優れ，また，架橋時にマグネシアなどを 配合寸ると, 耐窒素酸化物性に優れるとともに耐油性, 耐寒性，耐熱老化性のバランスに優れた組成物が得られ Ђ $^{29)}$.

\section{6. アクリルゴム}

アクリルゴムは歴史ある耐熱性，耐油性のゴムである が，加工性などに難点がある。この欠点を改良したアク リルゴムが開発された.このゴムの加硫の迅速さや平坦 性は新しい架橋点をつくるためのモノマーを導入するこ とによって解決された．この架橋用モノマーとしては， 八ロゲン含有モノマー，例えばビニルベンジルクロリド が少量用いられる.すなわち，エチルアクリレート， メ タアクリル酸, ビニルベンジルクロリドよりなるアクリ ルゴムでは，スコーチとキュアーの速度バランスに優 れ，この加硫ゴムは良好な物性バランスを有する30)。

硫黄架橋のでさるアクリルゴムも開発されだ!)。これ はアルキルアクリレートとエチリデンノルボルネルを共 重合させたもので，エチリデンノルボルネンのむつ不飽 
和基で通常の硫黄系や有機過酸化物による架橋ができ る.このアクリルゴムはジェン系のゴムとのプレンド使 用も可能であり ${ }^{32)}$ ，この架橋物は耐熱性，耐油性，耐工 ンジンオイル性などについては通常のアクリルゴムと同 等であるが，耐水性に優れている.

硫黄架橋型アクリルゴムの優れた耐熱性, 酎油性な どの加硫物性を維持し，反発弾性，屈曲疲労性などの欠 点を向上させるために，1４一ポリブタジエンが配合され る31). また，成型加工性に優れ，グリーン強度が大で， 架橋速度の早い組成物を得るために，ビニル結合が70\% 以上, 結晶化度 $5 \%$ 以上で固有粘度 $\left(30^{\circ} \mathrm{C}\right.$, トルエン) 0.7以上の1,2-ポリブタジェンが用いられる ${ }^{31)}$ ，イオウ 架橋型アクリルゴムの圧縮永久ひずみを改善するために NBR とのブレンドが武みられたが，耐熱性が低下し， また耐オソ゚ン性も悪くなる33)，そこで，これに乳化重合 したブタジェンーアクリルニトリルーブチルアクリレート からなる三元共重合体をブレンドした三元系ゴム組成物 とすると，アクリルゴムの欠点である圧維永久ひずみが 改善された金型よごれの少ないものが得られ，押出成形 品などに利用できる゙3)

アクリル酸エステルとブテンジオン酸モ/エステルの 二元共重合エラストマー，更にこれにエチレンを加えた 三元共重合エラストマーは，低温特性，高温特性，耐油 性が良好であるが，このポリマーの製造時に装置に腐蝕 が生じやすいという久点がある33!．この欠点を改善する ために，カルボン酸基含有モノマーにかえて不飽和グリ シジルエステルを用いると, 耐熱性, 耐低温特性, 耐油 性に優れた組織物を与えるエラストマーが得られる34).

\section{7.エチレンー酢酸ビニルーアクリル酸 エステル共重合エラストマー}

エチレン, 酶酸ビニル, アクリル酸エステルよりなる 三元共重合エラストマーが開発された ${ }^{35 !}$ ：このエラスト マーの耐熱性はクロロスルホン化ポリエチレンとエピク ロルヒドリンゴムの中間にあり，耐熱性はエピクロルヒ ドリンからクロロプレンゴム程度である．耐油性の優れ たものは高ニトリルNBR と同等で, 耐サワーガソリン 性にも優れ，高ニトリルNBRで耐熱性が不充分な分野 に利用できる ${ }^{35\}}$ 。耐燃料油性よりも酎潤滑油性を生かし た分野への応用に優れるであろう。

\section{8. $そ の$ 他}

8.1 ホスホニトリルフルオロエラストマー このエラストマーは, フッ素含有エラストマーのむつ
優れた耐溶剂性とフォスファゼン固有の低温可撓性 (ー50ㄷをで），耐熱性，耐酸化性，耐オゾン性を結びつ けたポリマーである，応用面では，耐油性，耐寒性を生 かした極地用の燃料ホースや航空機用ゴム製品への利用 が検討されている。

\section{2 熟可塑性ポリエステルエラストマー}

熱可塑性プラスチックと同じように加熱して加工でき るポリエステルェラストマー，Hytrel は耐熱性，酎油 性に優れ，一51 $150^{\circ} \mathrm{C} の$ 広い温度範囲で使用可能であ る.このエラストマーは飽和ポリエステルで，良好な耐 油性に加えて，耐オゾン性，耐候性に優れる.

\section{3 新しいフッ素含有特殊エラストマー}

航空機の燃料タンク用シール材として，超音速機など に利用できる新しいフッ素含有エラストマーが開発され た、このエラストマーは m-ジブロモベンゼンとメチル (3,3,3-トリフルオロプロピル)シリルクロリドを用いて 合成される ${ }^{36)}$.

\section{4 ジハロシクロプロパン化ポルブタジエン37)}

シスー1,4-ポリブタジエンの二重結合の 5 ７5\%をジ ハロシクロプロパン化したポリマーはアルコール含有ガ ソリンの透過性に対し高い抵抗性を持ち，自動車の燃料 系統のゴム材料などに適する。

8.5 ヘキサクロロシクロペンタジエン-1,5-シクロオ クタジエン付加物とシクロオレフィンとの共重台 体 $^{38)}$

六塩化タングステンとジオキシ化合物との反応混合物 と有機アルミニウム化合物を用いて共重合させて得た題 記のポリマーは, 耐油性, 耐薬品性, 難燃料に優れる.

\subsection{1 -アセトキシー1,3-ブタジエン(共)重合エラスト マ-39)}

1-アセトキシー1,3-ブタジエンの単独重合ポリマーあ るいはアクリレート，ブタジエンなどとの共重合ポリ マーは，容易にイオウなどで架橋ができ，優れた耐油性 を持っ架橋組成物を与える。

\section{荎 考 文献}

1）木村都成：“合成ゴム基礎講座”，大成社，p. $46 な$ どより作成

2）例えば，福島 宏：機能材料，3[2]，26（1983）

3）下川善春 : 発酵と工業, 42[6], 505 (1984)

4) Abu-Isa, I. A.: Rubber Chem. Technol., 56[1], 135 (1983)

5) Nersasian, A.: Elastomerics, 112[10], 26 (1980)

6）日本ゼオン，特公昭56-5465

7) Hindmarch, R. and Morrell, S.: Europ. Rubber J., 
162[3], $9(1980)$

8) 日本ゼオン，特開昭56-2940

9）福島 宏，尾山元文：ポリマーの友，20[8]，487 (1983)

10) Thörmer, J., Marwede, G., Buding, H.: Kautschuku, Gummi-Kunststoffe, 36[4], 269 (1983)

11）日本合成ゴム，特開昭59-49212

12）トヨ夕自動車, 特開昭58-5347, 76247, 76261

13）東海ゴム工業，特開昭55-89338

14）日本合成ゴム，特開昭58-25336

15) Killgoar, Jr,, P. C., Lemieu, M. A.: Rubber Chem. Technol., 56[4], 853 (1983), Ford France, ヨーロッパ 特許77628

16) Worm, A. T., Brullo, R. A.: Elassomerics, 115[9], 17 (1983)

17) Pugh, T. L.: ibid., 116[6], 35 (1984)

18) Thibeau, R. J.: Ind. Eng. Chem., Prod, Res. Dev. 22, * 127 (1983)

19) Chemical Marketing, Reporter, April 6, 1981, p. 7

20）建元正祥，河内正治：機能材料，3[7],32（1983）

21）ダイキン工業, 特開昭59-59749
22）石油化学新聞日刊通信，1984年 4 月26日p. 7

23）TC Mfg. Co., 米国特許4374874

24）ダイキン工菜，特開昭58-59275

25）奥本忠興，杉本正俊，市川昌好，日ゴ么協誌， 56[12], 784 (1983)

26）東海ゴム工業，特開昭57-162335〜6

27）日本合成ゴム，特開昭58-101037

28）豊田合成，特公昭58-33890

29）大阪曹達，特開昭58-2343

30) Goodrich, B. F., 特開昭58-210905

31）三ッ星ベルト，特公昭52-30311，57-60374〜 5，日 本ゼオン，特開昭54-127493

32）福森徳郎, 廷与弘次, 高嶋正昭 : ポリマーの友, 20[8], 475 (1983)

33）日本合成ゴム，特開昭57-25342

34）住友化学工業, 特開昭55-145745

35）高橋弘媇：ポリマーの友，20[8]，480 (1983)

36）化学工業時報，1979年11月14日，p. 10

37）宇部興産, 特開昭58-111813

38) GoodyearTyre \& Rubber，特開昭57-212227

39）日本合成ゴム，特開昭58-34836

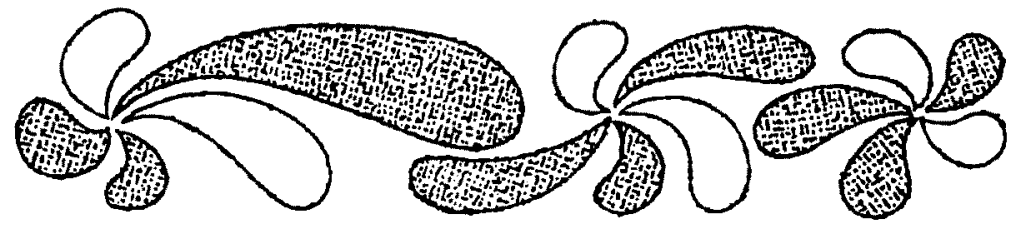

